IRA-International Journal of Management \& Social Sciences

ISSN 2455-2267; Vol.06, Issue 03 (2017)

Pg. no. 365-383

Institute of Research Advances

https://research-advances.org/index.php/RAJMSS

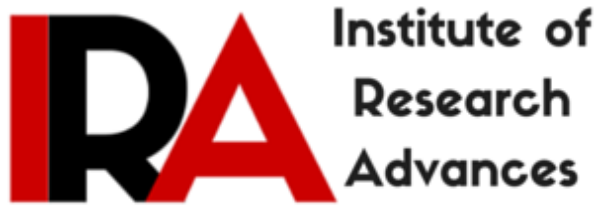

\title{
Micro-Finance \& Micro-Credit for Sustainable Development
}

\author{
${ }^{1}$ Prof. Shital Prakash Bhusare \\ Assistant Professor, \\ Sinhgad Institute of Business Administration \& Research, Pune, India. \\ ${ }^{2}$ Dr. Ruby Chanda \\ Associate Professor, \\ Sinhgad Institute of Business Administration \& Research, Pune, India.
}

Type of Review: Peer Reviewed.

DOI: http://dx.doi.org/10.21013/jmss.v6.n3.p4

\section{How to cite this paper:}

Bhusare, S., \& Chanda, R. (2017). Micro-Finance \& Micro-Credit for Sustainable Development. IRA-International Journal of Management \& Social Sciences (ISSN 24552267), 6(3), 365-383. doi:http://dx.doi.org/10.21013/jmss.v6.n3.p4

(C) Institute of Research Advances

(c) BY-NC

This work is licensed under a Creative Commons Attribution-Non Commercial 4.0 International License subject to proper citation to the publication source of the work.

Disclaimer: The scholarly papers as reviewed and published by the Institute of Research Advances (IRA) are the views and opinions of their respective authors and are not the views or opinions of the IRA. The IRA disclaims of any harm or loss caused due to the published content to any party. 


\begin{abstract}
Poverty is one of the biggest challenges to the development of a developing country like India where a major population is living in rural and semi-urban areas. Institutional credit is considered as a powerful tool for alleviating poverty. Microfinance is the supply of loans, savings, and other basic financial services to the poor. As the financial services of microfinance usually involve small amounts of money small loans, small savings etc. the term "Microfinance" helps to differentiate these services from those of commercial banks. Microfinance in India has been through two channels of credit delivery to poor and low-income households-Self Help Group Bank Linkage Programme (SBLP) and the Microfinance institutions lending through groups as well as directly to individuals. This study was with the overall objective of conducting a detailed analysis of interest rates, costs and margins of microfinance institutions.

This study highlights the reach and the impact on the customers and the channels used by these firms for the effectiveness of Micro Finance and Microcredit schemes. For the purpose of analysis the statistical tools like Mean, Standard deviation, coefficient of co-relation and regression have been used.

Microfinance is playing a very important role in decrease poverty. Microfinance to the rural SHGs is a way to raise the income level and improve the living standards of the rural peoples. Thus, it can be concluded that the self-help groups contribute substantially in pushing the conditions of the rural population up.
\end{abstract}

KEYWORDS: Microfinance, Micro Loans, Self Help Group Bank Linkage Programme (SBLP), Interest Rates, Cost.

\title{
INTRODUCTION
}

Institutional credit is considered as a powerful tool for alleviating poverty. Microfinance is the supply of loans, savings, and other basic financial services to the poor. As the financial services of Microfinance usually involve small amounts of money - small loans, small savings etc. the term "Microfinance" helps to differentiate these services from those of commercial banks. Microfinance in India has been through two channels of credit delivery to poor and low-income households - Self Help Group Bank Linkage Programme (SBLP) and the Microfinance institutions lending through groups as well as directly to individuals. Both these models which evolved and grew gradually during the 1990s, registered a blistering pace of growth in outreach and portfolios in the next decade. However, the MFI segment has grown over 20 times in the last 5 years from INR 8.97 billion loans outstanding in 2005, the MFIs reached the position of INR 183.44 billion loan outstanding in 2010. The SBLP program comparatively has grown at $30 \%$ year on year during the same period. In the last 5 years, the Microfinance operations that were earlier concentrated in the southern and eastern states began to spread to other poorer regions with the large MFIs expanding their operations to these regions as well as with the emergence of local new age institutions.

MFIs have been relatively faster in reaching out the under-served population even in the most difficult geographical regions of India. The MFI channel culminated in last decade in terms of its outreach, product diversity and technological innovation. However, as the sector scaled up, absence of a conducive regulatory framework along with few other political factors caused the Andhra Pradesh crisis in 2010. Due to the crisis the MFIs have suffered a huge loss in terms losing their loan portfolios. Moreover, as the Banks stopped lending to MFIs, they have not been not been able to disburse fresh loan to their clients. This has been also been a huge setback to the low income people across India that were being benefitted by the Microfinance services from the MFIs.

In the aftermath of the crisis, all stakeholders of industry have shown their commitment to introspect and restrengthen the sector. Small Industries Development Bank of India (SIDBI) having played a key role in the development of Microfinance in India commissioned this study for carrying out a 
detailed analysis of interest rates, costs and margins and product pricing of SIDBI assisted Microfinance institutions. ACCESS Development Services carried out the study.

An as apex development finance institution, Small Industries Development Bank of India (SIDBI) has played a significant role in the development and growth of Microfinance in India through the SIDBI Foundation for Micro Credit (SFMC). SFMC is the apex wholesaler for Microfinance providing a complete range of financial and support services enabling the growth of MFIs. These services have enabled the Microfinance institutions, especially in their initial stage of development, to invest in systems and institution building, imbibe sound practices. Based on credit history created with SIDBI, the MFIs could access commercial funding; both debt and equity, which in turn fuelled the portfolio and outreach growth. The sector building role played by SFMC has contributed to development of technical service providers for the MFIs, which enabled their growth.

The research addresses the lack of access of the underserved segments of the population to financial services, an important constraint to improved productivity and incomes, and particularly in the aftermath of dual crises that have affected the Microfinance sector in India; the global financial crisis which continues to affect MFIs and their clients, and more importantly the impact of the crisis in Andhra Pradesh, which has caused a precipitous drop in repayment in the affected region of the country, and may significantly undermine the outreach and sustainable of the sector throughout India. The study is a part of the component. Strengthening Responsible Finance' which addresses many of the root causes of the AP crisis, and provides solutions for taking on the responsible finance agenda at such a critical time for the future of the Microfinance sector. In particular, the Project strengthens the Responsible Finance agenda through creation of a Lenders' Forum, development of a common information platform similar to the Global Mix Market and formalizing of a system for monitoring of the Microfinance Code of Conduct, among others.

Table 1

Features of Microfinance Approaches ${ }^{1}$

\begin{tabular}{|c|c|c|c|}
\hline Features & $S H G$ & Grameen & Individual Banking \\
\hline Clients & Primarily women & Primarily women & Primarily men \\
\hline Groups & $15-20$ clients per group & $\begin{array}{c}\text { Usually } 5 \text { clients per group } \\
\text { (organised into centres of 4-6 } \\
\text { groups) }\end{array}$ & Individual clients \\
\hline Services & Savings and credit & Credit-regular cycle & Credit \\
\hline Role of MFI staff & Guide and facilitate & $\begin{array}{c}\text { Organise } \\
\text { (groups dependent on staff) }\end{array}$ & Organise \\
\hline Meetings & Monthly & Weekly & $\begin{array}{c}\text { Individual transactions } \\
\text { - often daily }\end{array}$ \\
\hline Savings deposits & Rs $20-100 /$ month & Rs 5-25/week & Flexible \\
\hline Interest on savings & $\begin{array}{c}\text { Bank rate } \\
(4.25 \text { per cent)+profit share }\end{array}$ & 6-9 per cent & 6 per cent + \\
\hline Initial loan amount & Rs $5-10,000$ & Rs $2-5000$ & Rs $5-15000$ \\
\hline Effective interest rate & 24-28 per cent & $32-38$ per cent & 23-38 per cent \\
\hline Insurance & $\begin{array}{l}\text { Sometimes loans linked to } \\
\text { health and life insurance }\end{array}$ & $\begin{array}{l}\text { Sometimes loans linked } \\
\text { to health and life insurance }\end{array}$ & $\begin{array}{l}\text { Sometimes loans linked to } \\
\text { health and life insurance }\end{array}$ \\
\hline Development services & Some associated programmes & Small social projects & Enterprise support \\
\hline
\end{tabular}

Adapted from Sinha (2005). 


\section{OBJECTIVES OF THE STUDY}

The proposed research study has the following objectives:

- To study the existing interest rate structures of various MFIs.

- To study the channels used and its impact on the customers of MFIs

- To study the credit collection methods being devised by MFIs.

- To suggest enduring solutions for the effective service delivery of MFIs.

\section{SIGNIFICANCE OF THE STUDY}

- To study the various financial products being offered to the farmers by MFI's

- To identify the reasons of high interest rates charged by the MFIs.

- Easing of Interest rates by cutting operating costs through better service delivery.

- This study will also help in making MFIs a better tool for socio-economic development.

\section{RESEARCH METHODOLOGY}

a) Research Design - The study proposes to adopt a 'Descriptive Research Design'. This design is most appropriate as the research studies the systems and processes in detail to explore the possibilities of reduction in the operating costs of MFIs and thus to suggest a cost-effective service delivery system based on the data collected. The research proposes to depend on both Secondary and Primary sources of data.

For secondary data references would include policy documents of regulatory bodies \& MFIs, research papers on the subject, articles by experts etc.

Secondary data collected and utilized in the study is limited to the purpose of benchmarking the trends of the sample with regional and global data.

For collection of primary data the research proposes to design a structured questionnaire to be circulated and filled by representatives of MFIs and also borrowers of micro-credit in Maharashtra State. A sample of 15 respondents of MFIs was taken for the study from Maharashtra State.

\section{i) Organizational Information:}

ii) Semi-Structured Interviews:

$\checkmark \quad$ MFI Senior management (CEO, CFO, COO)

$\checkmark \quad$ MFI Staff(Operations manager, Branch/Area manager)

$\checkmark \quad$ MFI Clients

$\checkmark \quad$ Stakeholders - technology service providers, banks/lenders, investors and financial experts

\section{Sampling Plan}

Population - Micro-financing Institutions in Maharashtra

Sampling Frame - Government of Maharashtra \& RBI database

Sampling Design - Simple random sampling

Sample size - 15 MFIs and 50 borrowers

\section{Data Analysis}

Data collected was edited for accuracy, uniformity, consistency, completeness and arranged to enable coding and tabulation before final analysis. The data was then entered into a computer program called Statistical Package for Social Sciences (SPSS Version 16) for analysis and interpretation.

\section{LITERATURE REVIEW}

Interdisciplinary Relevance

The characteristic of interest of the research problem in question, that is service delivery of MFIs is relevant to the beneficiaries of micro-credit, micro-mortgages, micro-insurance that covers the majority of the rural population. Therefore the problem not only addresses the social issues but also has economic, marketing and developmental dimensions. The scope of the proposed study, therefore, is not limited to 
any particular discipline. It is rather all-encompassing covering the conduct of systems and processes through which MFIs work and provide services, which while up-lifting the poor sections of society will contribute towards economy in general \& financial inclusion in particular.

\section{Review of Research \& Development in the Subject International Status:}

A few research studies include:

\section{* Sustainability of MFI from small farmer's perspective: A case of Rural Nepal}

Conclusion of this study was that the small farmers who involved in executive committee for more than a year were more concerned about institutional sustainability than others. It is revealed that small farmers generally do not think in terms of institutional sustainability when they borrow the loans. The majority of non-executive small farmers had a little concern about 'institutional' sustainability.

\section{* CERMI: Centre for European Research in Microfinance conducts many research studies on Microfinance}

From a microeconomic and managerial perspective, CERMi is undertaking research on institutional aspects including governance and risk management of Microfinance institutions, as well as the concept of a client-driven approach toward the development of financial services and products. From a macroeconomic and sociological point of view, CERMi focuses on matters of regulation and local government policy, as well as the roles played by central banks and international donors. Links between Microfinance and the traditional banking sector are also analyzed, and throughout this research, special attention is given to ethical considerations that are specifically relevant and critical to the evolution of the Microfinance industry.

\section{* Strengthening internal controls of MFIs in Tajikistan: A project initiated by World Bank}

The development objective of the Tajikistan's Second Poverty Alleviation Project is to improve the living standards of poor and vulnerable people through micro-projects, micro-finance services, and community empowerment in areas served by the project.

* Lot of academic efforts involving stakeholder participation are visible through, formal and informal efforts for gathering expert opinion from the industry for various issues relating to high interest rates.

Microfinance institutions' (MFIs) high interest rates have been at the center of controversy from the beginning of Microfinance. One plausible and widely accepted theory, which explains MFIs' high interest rate puzzle, is that there exist fixed costs involved in making loans, say per borrower (or per loan) fixed transaction costs. However, in spite of its topicality, this fixed costs theory still remains untested empirically. Based on the theoretical operating costs function and a large data set on 534 MFIs from 75 countries, this study is the first attempt to test the fixed costs theory directly, by answering the following questions: how much of operating costs are incurred by per borrower fixed transaction costs?

\section{National Level}

At the national level, the Indian Microfinance sector presents a strong growth story. Its growth performance was impressively sustained even during the liquidity crunch. As of March 2009, MFIs in India reported a client base of $22.6 \mathrm{mn}$ with an outstanding portfolio of more than $\$ 2$ billion. But the recent controversy has forced the academicians to undergo research study regarding MFIs. Some of the research works being conducted at the national level are:

\section{- Bringing Rural India into Growth Fold: A project by NABARD}

NABARD has played a pioneering role in Financial Inclusion by extending formal banking services to the unreached rural poor by evolving supplementary credit strategies in a cost effective manner by promoting Self Help Groups (SHGs), Joint Liability Groups (JLGs), Farmers' Clubs (FCs), etc. 


\section{NABARD's Micro-finance Initiatives}

NABARD, during the early eighties, conducted a series of research studies, which showed that despite having a wide network of rural bank branches that implemented specific poverty alleviation programmers and self-employment opportunities, a very large number of the poor continue to remain outside the fold of the formal banking system.

\section{SHG-Bank Linkage Scheme}

Against this background, a need was felt for supplementary policies, systems and procedures, savings and loan products, other complementary services, and new delivery mechanisms, which would fulfill the requirements of the poor, especially of the women members of such households.

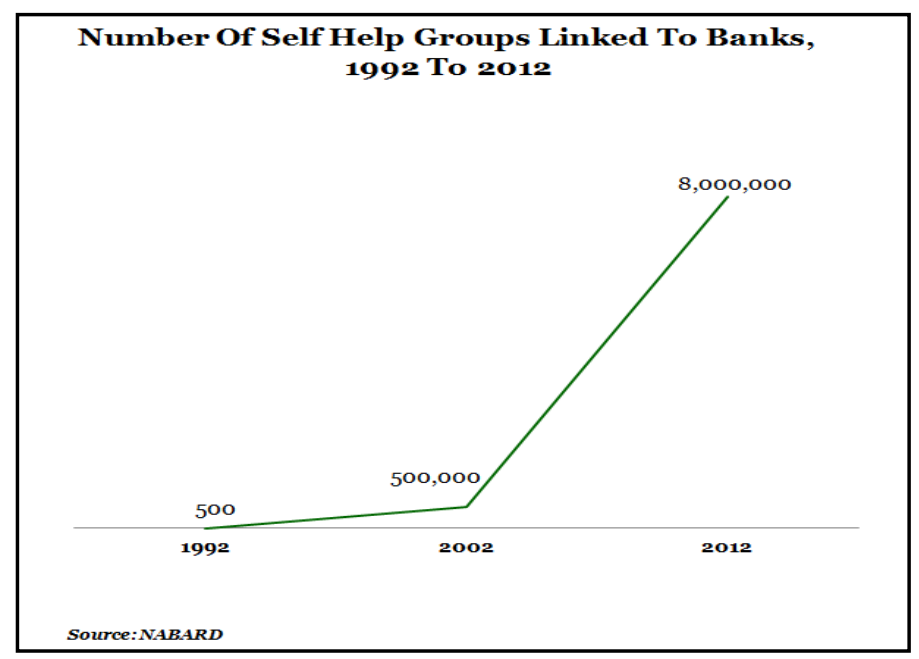

\section{Self Help Group- Bank Linkage Programme}

1. Government started it in 1992.

2. SHGs are informal associations of poor people who come together to acquire financial services.

3. The programme works on a group lending model wherein being a member of an SHG gives many incentives to the poor.

4. Incentives are in the form of ease in access to financial services, lower interest rates (especially for women SHGs) and training programmes for entrepreneurship.

\section{NABARD-UNDP Collaboration}

This apart, NABARD and UNDP have entered into collaboration for financial inclusion in seven focus states viz. Bihar, Chhattisgarh, Jharkhand, Madhya Pradesh, Orissa, Rajasthan and Uttar Pradesh. This collaboration is part of the Country Programme Action Plan (CPAP) signed between Government of India and the UNDP.

The project budget for the annual work plan 2009 was US $\$ 2,98,335$, which is being provided by UNDP. A sensitization workshop for the Officer-in-charge of the seven focus state regional officers has been conducted and projects have been initiated under NABARD-UNDP collaboration for financial inclusion.

\section{- Task-force on Supportive Policy and Regulatory Framework for Microfinance : A project by} NABARD

Microfinance (MF) is being practiced as a tool to attack poverty the world over. During the last two decades, substantial work has been done in developing and experimenting with different concepts and approaches to reach financial services to the poor, thanks mainly to the initiatives of the NonGovernmental Organizations (NGOs) and banks in various parts of the country. 


\section{DATA ANALYSIS}

\section{LENDERS}

1. Which of the following describes your MFI's lending profile? ( $\mathrm{Y}-\mathrm{Yes} ; \mathrm{N}-\mathrm{No}$ )

\begin{tabular}{|c|c|l|c|c|c|}
\hline $\begin{array}{l}\text { Organization } \\
\text { Lending } \\
\text { Profile/ } \\
\text { Response }\end{array}$ & $\begin{array}{l}\text { Lend to } \\
\text { individuals who } \\
\text { are members of a } \\
\text { credit group }\end{array}$ & $\begin{array}{l}\text { Provide loans to } \\
\text { micro entrepreneurs } \\
\text { whose businesses } \\
\text { generate a weekly } \\
\text { cash flow }\end{array}$ & $\begin{array}{l}\text { Require group } \\
\text { guarantee of } \\
\text { the loans made } \\
\text { to members }\end{array}$ & $\begin{array}{l}\text { Loan at } \\
\text { commercial } \\
\text { interest rates }\end{array}$ & $\begin{array}{l}\text { Require } \\
\text { members to } \\
\text { save }\end{array}$ \\
\hline Yes & 13 & 11 & 13 & 9 & 14 \\
\hline No & 2 & 4 & 2 & 6 & 1 \\
\hline
\end{tabular}

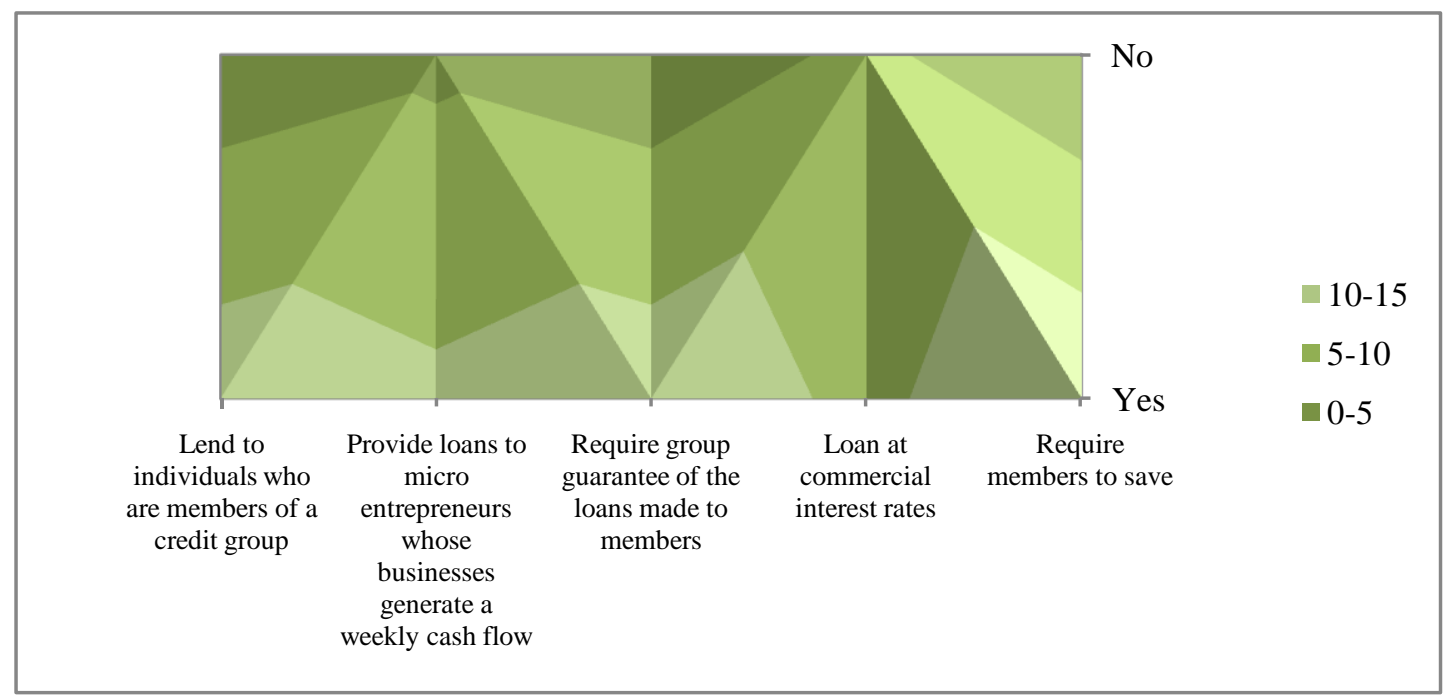

Inferences: Most of the respondents agree that they lend to individuals who are members of a credit group, provide loans to those whose businesses generate weekly cash flow, require group guarantee of loans, lend at commercial interest rates and require members to save. Thus it indicates that the lenders take precautionary step towards lending sentiment about their businesses in the market.

2. What kinds of institutions deliver financial services to poor clients?

\begin{tabular}{|l|l|l|l|l|l|}
\hline Response & $\begin{array}{l}\text { microfinance } \\
\text { institutions }\end{array}$ & credit unions & cooperatives & banks & $\begin{array}{l}\text { mobile network } \\
\text { operators }\end{array}$ \\
\hline Number & 5 & 3 & 3 & 2 & 2 \\
\hline
\end{tabular}




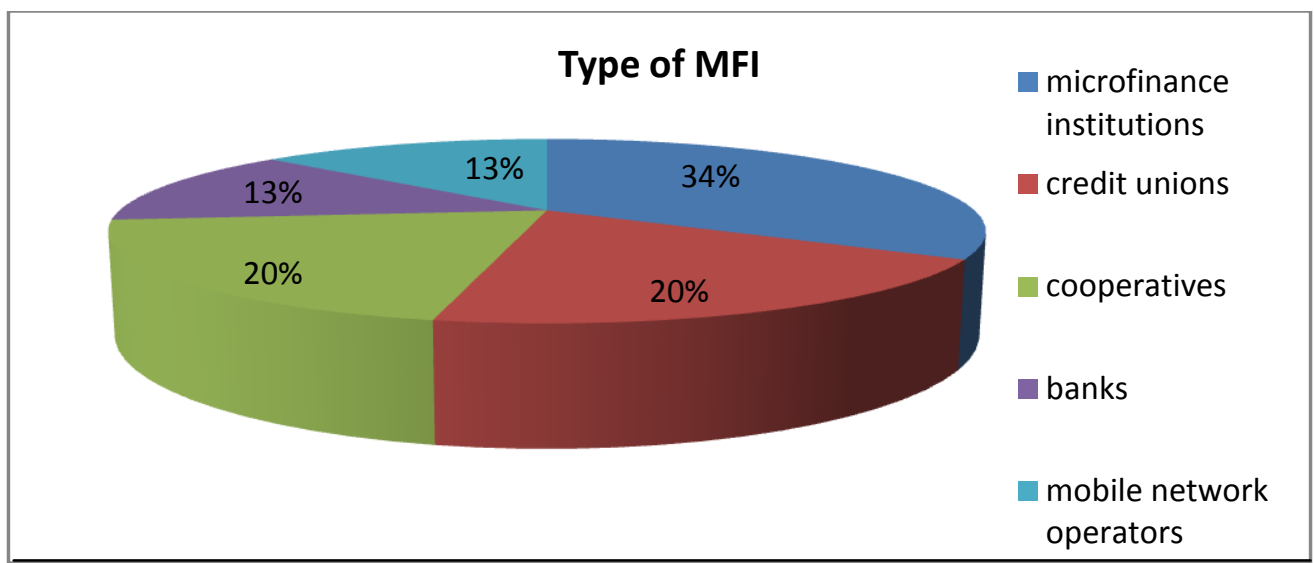

Inferences: Banks are still not active in providing microfinance to the root level.

3. How much effective is the channel from whom they procure MFI? Rate the following as reasons for microloan repayment on the degree of importance. (5: very good \& 1: Very bad)

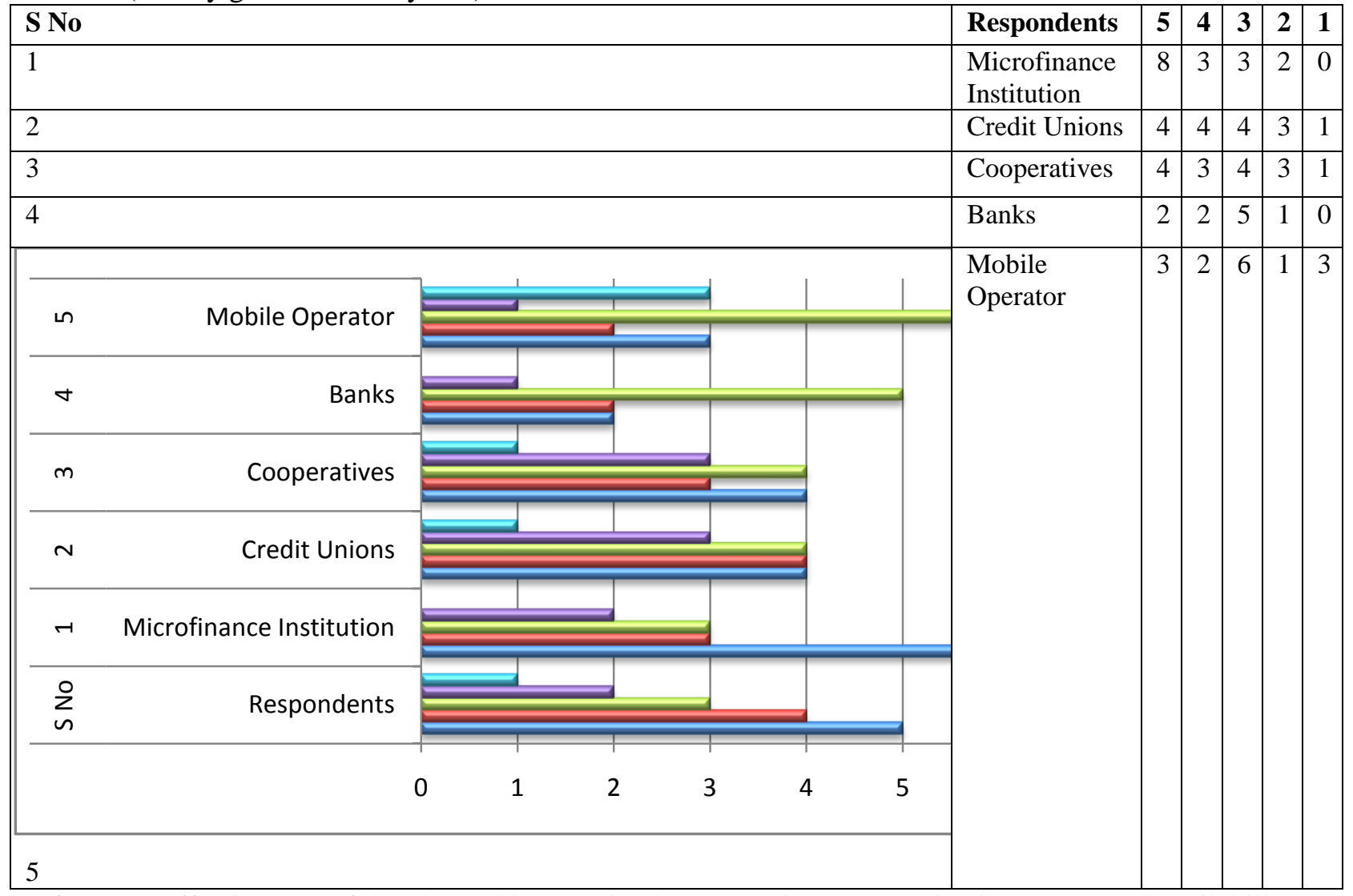

Inference: Effectiveness of the channel is rated by the respondents as per the time taken and availability of the channel to the customer. Also it includes the processing in reaching out.

4. Your MFI's microloan default rate (in \%)

Inferences: Most of the respondents did not respond to this question as it will give a negative 
Rate the following as reasons for microloan repayment on the degree of importance. (5: very good \& 1 : Very bad)

\begin{tabular}{|r|l|l|l|l|l|l|}
\hline S.N. & \multicolumn{1}{|c|}{ Reasons } & $\mathbf{5}$ & $\mathbf{4}$ & $\mathbf{3}$ & $\mathbf{2}$ & $\mathbf{1}$ \\
\hline a) & Client savings & 11 & 4 & 0 & 0 & 0 \\
\hline b) & Low interest rates & 10 & 5 & 0 & 0 & 0 \\
\hline c) & Group peer pressure & 9 & 6 & 0 & 0 & 0 \\
\hline d) & Client access to future loans & 9 & 6 & 0 & 0 & 0 \\
\hline e) & Regular monitoring by program members & 11 & 4 & 0 & 0 & 0 \\
\hline f) & Careful application screening mechanism & 12 & 3 & 0 & 0 & 0 \\
\hline
\end{tabular}

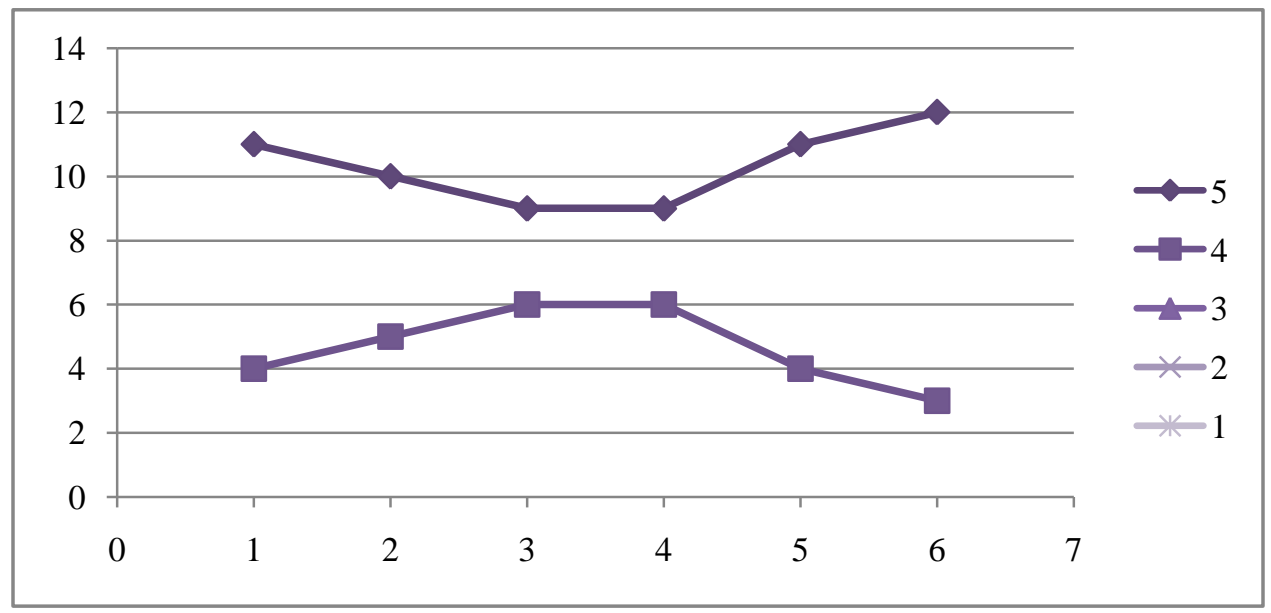

Inference: Most of the respondents agree towards the importance of Client savings, low interest rates, group peer pressure, access to future loans, regular monitoring by program members and careful application screening as important factors for loan repayment.

5. Have you/your clients been impacted in following ways after MFI support/association? (5: very good \& 1: very bad)

\begin{tabular}{|r|l|l|l|l|l|l|}
\hline S.N. & \multicolumn{1}{|c|}{ Parameter } & $\mathbf{5}$ & $\mathbf{4}$ & $\mathbf{3}$ & $\mathbf{2}$ & $\mathbf{1}$ \\
\hline a) & Added new products or services & 9 & 6 & 0 & 0 & 0 \\
\hline b) & Improved or expanded their enterprise premises & 10 & 2 & 3 & 0 & 0 \\
\hline c) & Moved to new premises or sold in new markets & 9 & 3 & 3 & 0 & 0 \\
\hline d) & Reduced costs by buying in bulk & 12 & 1 & 2 & 0 & 0 \\
\hline e) & Increased their sales volume & 8 & 7 & 1 & 0 & 0 \\
\hline f) & Began a new enterprise & 10 & 1 & 4 & 0 & 0 \\
\hline g) & Increased the amount spent on durable assets & 9 & 4 & 2 & 0 & 0 \\
\hline h) & Increased the amount of household income & 11 & 1 & 2 & 1 & 0 \\
\hline i) & Increased the amount of money they spent on inputs & 9 & 2 & 3 & 1 & 0 \\
\hline j) & Increased the number of ways they save & 10 & 2 & 3 & 0 & 0 \\
\hline k) & Increased their knowledge and skill base. & 9 & 4 & 2 & 0 & 0 \\
\hline
\end{tabular}




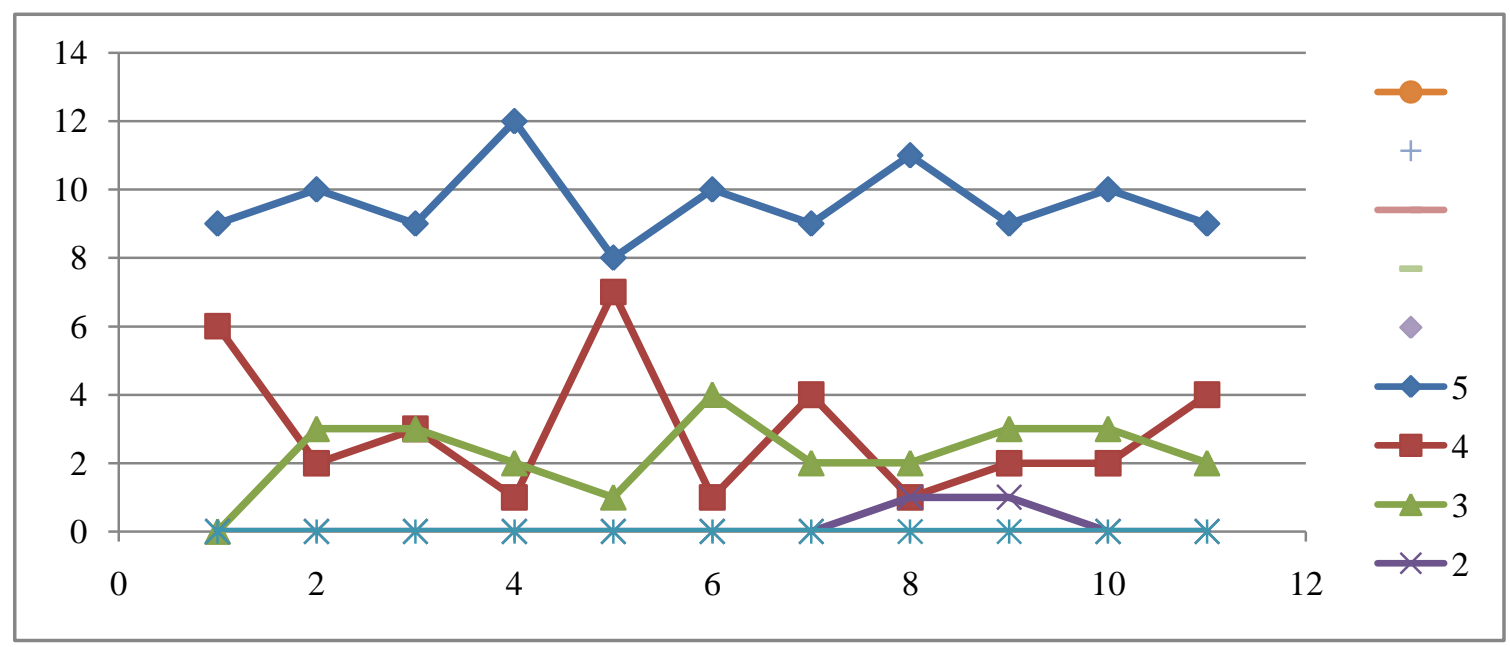

Inference: Most of the respondents agree that their clients were impacted through reduction in costs while buying in bulk and increased the household income.

6. What reasons trigger clients for leaving Micro finance institutions? (5: Strongly agree \& 1: Strongly Disagree)

\begin{tabular}{|r|r|l|l|l|l|l|}
\hline S.N. & Reasons & $\mathbf{5}$ & $\mathbf{4}$ & $\mathbf{3}$ & $\mathbf{2}$ & $\mathbf{1}$ \\
\hline a) & Lack of grace period & 0 & 1 & 2 & 7 & 5 \\
\hline b) & Interest rate too high & 0 & 0 & 1 & 4 & 10 \\
\hline c) & Inability to repay loan for family reasons & 0 & 0 & 0 & 2 & 13 \\
\hline d) & Didn't like program savings requirement & 0 & 0 & 2 & 2 & 11 \\
\hline e) & Didn't need loan anymore & 0 & 4 & 5 & 5 & 1 \\
\hline f) & Didn't like periodicity in repayment & 0 & 5 & 4 & 4 & 2 \\
\hline g) & Others (e.g., rude officials, sickness) & 0 & 7 & 6 & 2 & 0 \\
\hline
\end{tabular}

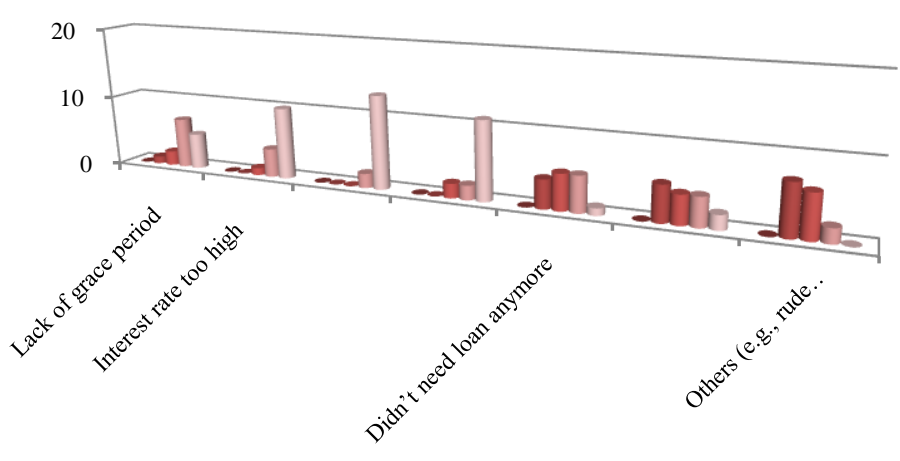


Inference: The respondents strongly disagree the reasons for leaving micro financing institutions such as interest rate too high, inability to pay loan for family reasons while they agree that reasons for leaving MFIs are did not need loan anymore and did not like periodicity in repayment. Thus higher interest rates are not at all reasons for leaving Micro Finance institutions.

7. Have you/your clients been impacted in following ways after MFI support/association? (5: Strongly agree \& 1: Strongly disagree)

\begin{tabular}{|c|l|l|l|l|l|l|}
\hline S.N. & $\mathbf{5}$ & $\mathbf{4}$ & $\mathbf{3}$ & $\mathbf{2}$ & $\mathbf{1}$ \\
\hline a) & Learned savings skills & 6 & 7 & 2 & 0 & 0 \\
\hline b) & Able to meet basic family needs & 6 & 7 & 1 & 1 & 0 \\
\hline c) & Business has grown & 5 & 9 & 1 & 0 & 0 \\
\hline d) & Business-related training was helpful & 4 & 3 & 7 & 1 & 0 \\
\hline e) & Able to pay school expenses & 5 & 5 & 4 & 1 & 0 \\
\hline f) & Have more household assets now & 3 & 3 & 6 & 2 & 1 \\
\hline g) & Have gained confidence and self-esteem & 3 & 2 & 7 & 1 & 2 \\
\hline h) & Now able to use money more optimally in household and business & 6 & 5 & 2 & 1 & 1 \\
\hline i) & Gained leadership experience & 3 & 2 & 6 & 2 & 2 \\
\hline j) & Other skills training was helpful & 3 & 3 & 3 & 5 & 1 \\
\hline k) & Have a place to put my savings & 5 & 6 & 2 & 2 & 0 \\
\hline
\end{tabular}

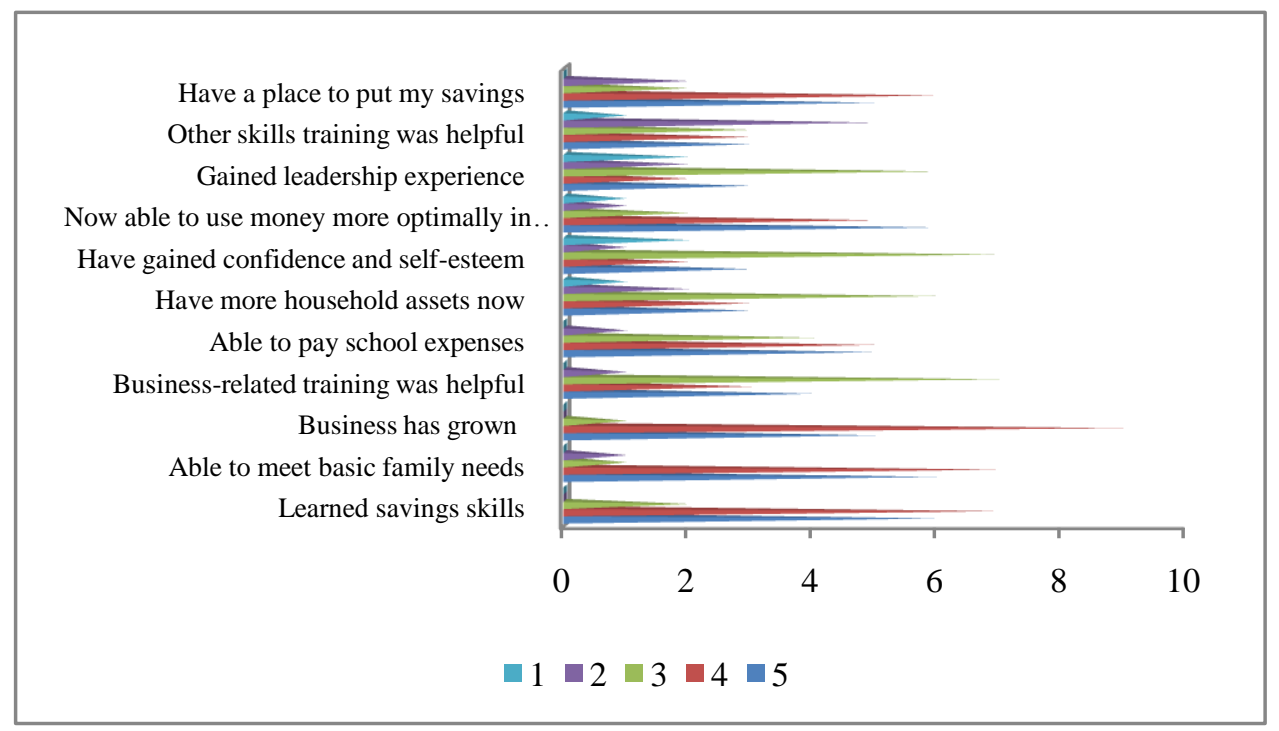

Inference: The respondents agree that their clients have been impacted positively on above mentioned variables

8. Do you think the following cost heads in providing Microfinance services work in your favor?

\begin{tabular}{|c|l|c|c|c|c|}
\hline S.N. & \multicolumn{1}{|c|}{ Cost Head } & $\begin{array}{c}\text { Above } \\
\text { Industry }\end{array}$ & $\begin{array}{c}\text { At par with } \\
\text { Industry }\end{array}$ & $\begin{array}{c}\text { Below Industry } \\
\text { Standards }\end{array}$ & $\begin{array}{c}\text { Can't } \\
\text { Say }\end{array}$ \\
\hline a) & Cost Per Active Client & 2 & 12 & 0 & 1 \\
\hline b) & Borrower per loan officer & 2 & 11 & 2 & 0 \\
\hline c) & Average Outstanding loan size & 1 & 13 & 1 & 0 \\
\hline d) & Average loan disbursed & 2 & 10 & 2 & 1 \\
\hline
\end{tabular}




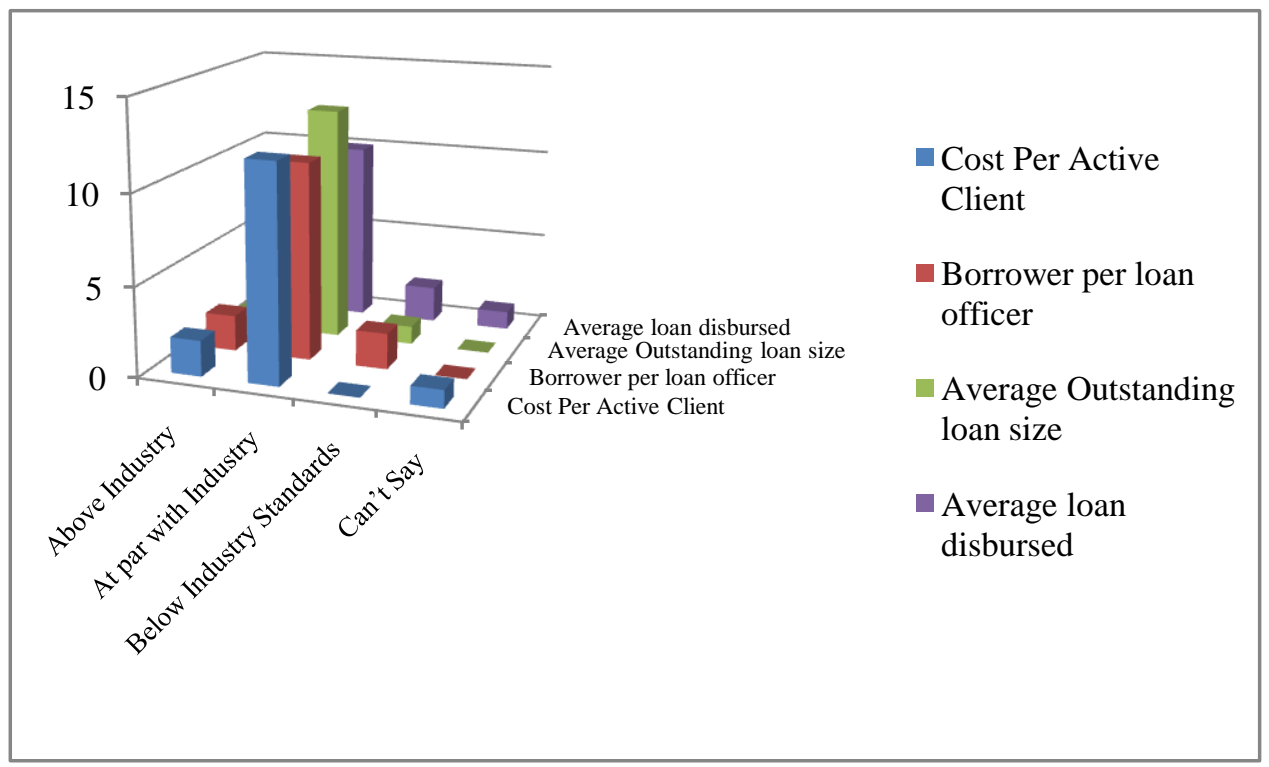

Inference: The respondents agree that the various cost heads like cost per active client, Borrower per loan officer, average outstanding loan size and average loan disbursed are at par with the industry.

9. How would you rate your services/your service provider on the following points? (5: very good \& 1: very bad)

\begin{tabular}{|r|l|c|c|c|c|c|}
\hline \multicolumn{1}{|c|}{ Parameter } & $\mathbf{5}$ & $\mathbf{4}$ & $\mathbf{3}$ & $\mathbf{2}$ & $\mathbf{1}$ \\
\hline a) & On time Service delivery & 12 & 2 & 1 & 0 & 0 \\
\hline b) & Exact and precise service delivery & 13 & 2 & 0 & 0 & 0 \\
\hline c) & Your service provider is dependable & 9 & 4 & 2 & 0 & 0 \\
\hline d) & They have delivered service as promised & 9 & 5 & 1 & 0 & 0 \\
\hline e) & You feel safe in all transactions with the service provider & 12 & 3 & 0 & 0 & 0 \\
\hline f) & Prompt response to customer request & 13 & 2 & 0 & 0 & 0 \\
\hline g) & Sincere interest in problem-solving & 5 & 10 & 0 & 0 & 0 \\
\hline h) & Responsiveness -Provision of adequate information & 12 & 3 & 0 & 0 & 0 \\
\hline i) & Advanced information about services & 14 & 1 & 0 & 0 & 0 \\
\hline j) & Reputation of service & 13 & 2 & 0 & 0 & 0 \\
\hline k) & Politeness of personnel's behavior & 6 & 9 & 0 & 0 & 0 \\
\hline l) & Cultivation of friendly relationship & 7 & 8 & 0 & 0 & 0 \\
\hline m) & Learning the customers' special needs & 6 & 6 & 3 & 0 & 0 \\
\hline n) & Allocating required time to deliver service & 7 & 7 & 0 & 1 & 0 \\
\hline o) & Modern and technologically relevant system & 3 & 12 & 0 & 0 & 0 \\
\hline
\end{tabular}




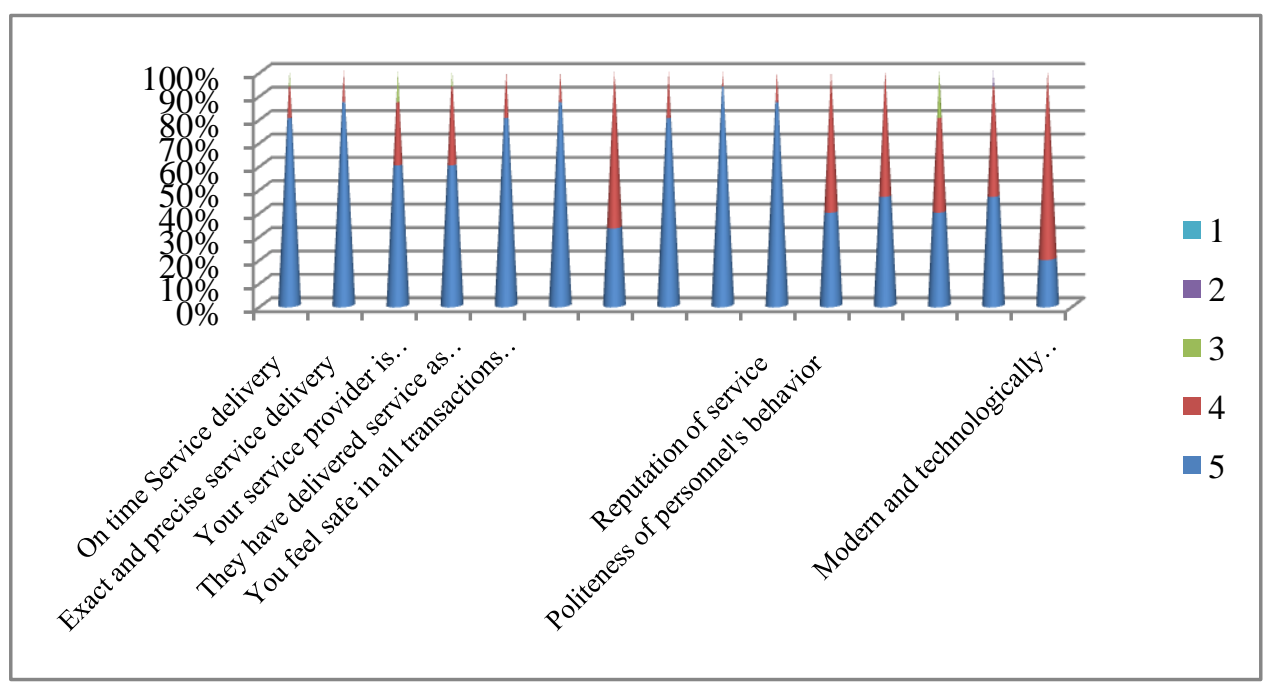

Inference: Majority of the respondents rate themselves very good on various services mentioned above.

\section{BORROWERS}

1. Description of the respondents:

\begin{tabular}{|c|c|c|c|c|c|}
\hline \multirow[t]{2}{*}{ Gender - } & Male & Female & Both & & \\
\hline & 34 & 17 & 51 & & \\
\hline \multirow[t]{2}{*}{ Age - } & Young & Middle-aged & Old & & \\
\hline & 19 & 20 & 12 & & \\
\hline \multirow[t]{2}{*}{ Occupation - } & Trade & Services & Manufacturing & Agriculture & Other \\
\hline & 5 & 46 & 0 & 0 & 0 \\
\hline \multirow[t]{2}{*}{ Region - } & Rural & Semi-Urban & Urban & & \\
\hline & 12 & 32 & 7 & & \\
\hline \multirow{2}{*}{$\begin{array}{l}\text { Participant in } \\
\text { SHG - }\end{array}$} & Yes & No & & & \\
\hline & 51 & 0 & & & \\
\hline
\end{tabular}

Inferences: Most of the respondents were male, middle aged from semi urban areas and they have participated through Self Help group. This shows that MFI's still has not penetrated in the rural areas.

2. Rate the following as reasons for microloan repayment on the degree of importance. (5: Strongly Agree \& 1: Strongly disagree)

\begin{tabular}{|c|l|l|l|l|l|l|}
\hline S.N. & \multicolumn{1}{|c|}{ Reasons } & $\mathbf{5}$ & $\mathbf{4}$ & $\mathbf{3}$ & $\mathbf{2}$ & $\mathbf{1}$ \\
\hline a) & Client savings & 35 & 10 & 6 & 0 & 0 \\
\hline b) & Low interest rates & 32 & 9 & 10 & 0 & 0 \\
\hline c) & Group peer pressure & 29 & 20 & 2 & 0 & 0 \\
\hline d) & Client access to future loans & 42 & 9 & 0 & 0 & 0 \\
\hline e) & Regular monitoring by program members & 37 & 10 & 4 & 0 & 0 \\
\hline f) & Careful application screening mechanism & 27 & 12 & 12 & 0 & 0 \\
\hline
\end{tabular}




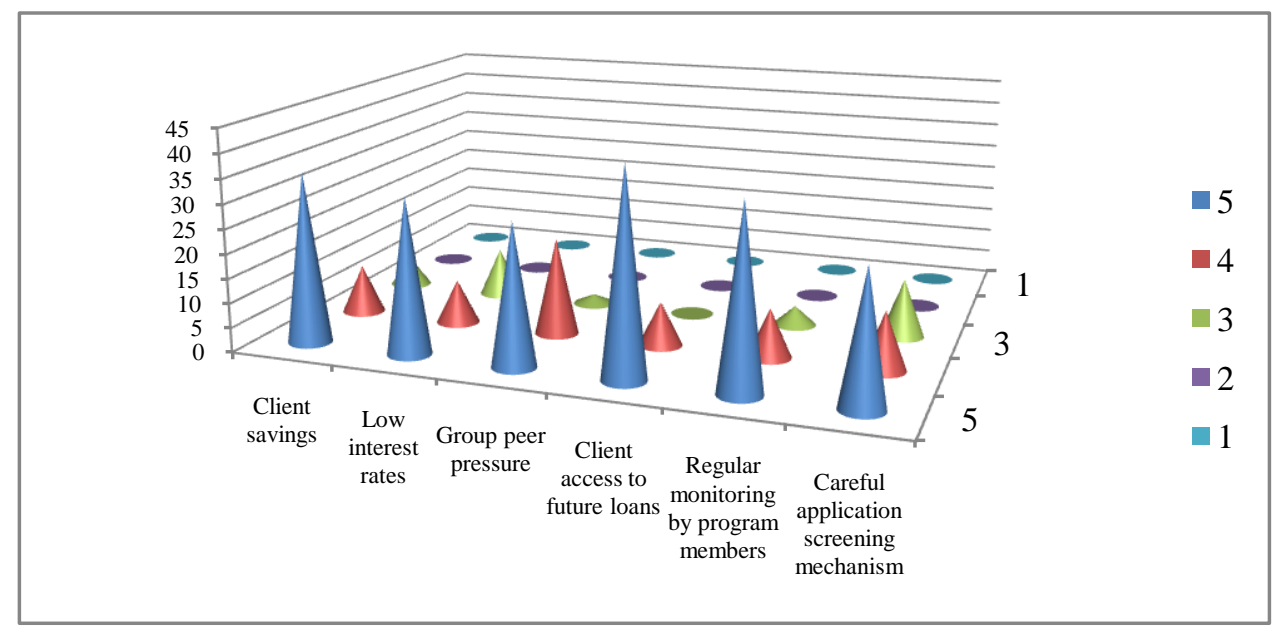

Inference: Most of the respondents agreed to their access to future loans as the important factor for micro loan repayment while moderate response was towards less interest rate and group peer pressure

3. Have you/your clients been impacted in following ways after MFI support/association? (5: Strongly Agree \& 1: Strongly Disagree)

\begin{tabular}{|r|l|l|l|l|l|c|}
\hline S.N. & \multicolumn{1}{|c|}{ Parameter } & $\mathbf{5}$ & $\mathbf{4}$ & $\mathbf{3}$ & $\mathbf{2}$ & $\mathbf{1}$ \\
\hline a) & Added new products or services & 32 & 10 & 6 & 3 & 0 \\
\hline b) & Improved or expanded their enterprise premises & 32 & 9 & 8 & 2 & 0 \\
\hline c) & Moved to new premises or sold in new markets & 32 & 18 & 0 & 1 & 0 \\
\hline d) & Reduced costs by buying in bulk & 42 & 9 & 0 & 0 & 0 \\
\hline e) & Increased their sales volume & 37 & 10 & 4 & 0 & 0 \\
\hline f) & Began a new enterprise & 27 & 15 & 9 & 0 & 0 \\
\hline g) & Increased the amount spent on durable assets & 32 & 13 & 6 & 0 & 0 \\
\hline h) & Increased the amount of household income & 32 & 9 & 10 & 1 & 0 \\
\hline i) & Increased the amount of money they spent on inputs & 40 & 11 & 0 & 0 & 0 \\
\hline j) & Increased the number of ways they save & 37 & 10 & 4 & 0 & 0 \\
\hline k) & Increased their knowledge and skill base. & 32 & 12 & 7 & 0 & 0 \\
\hline
\end{tabular}




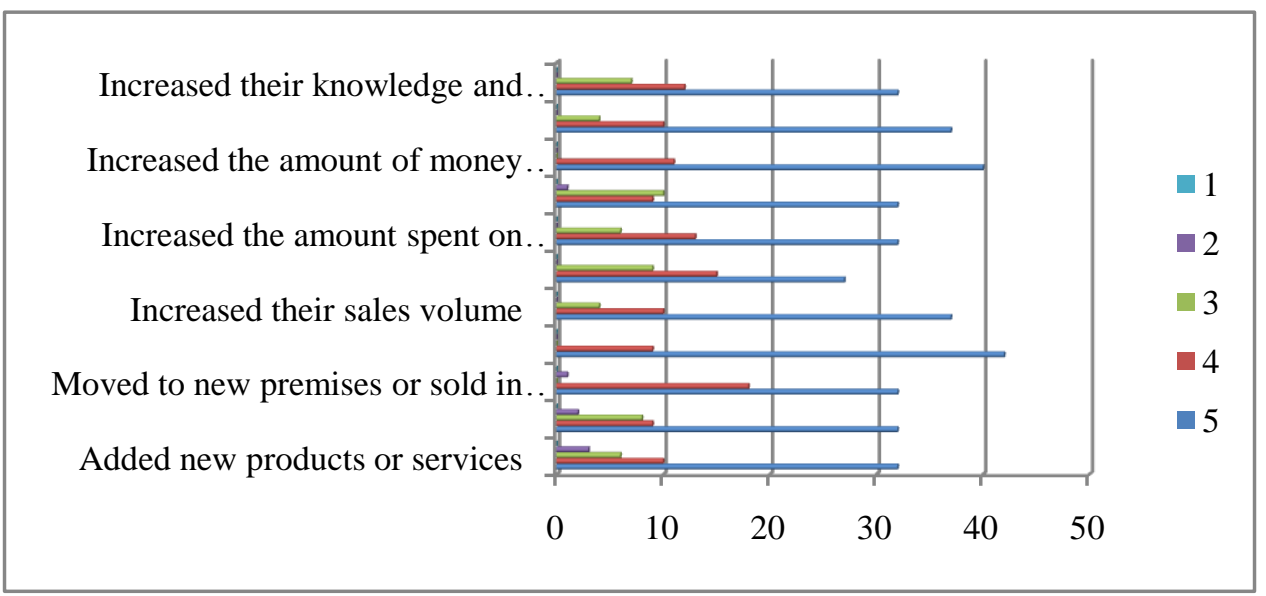

Inference: Most of the respondents agree that borrowing from MFI's help them to reduce costs by buying in bulk and increase the amount of money they spent on inputs. Thus they are positively being impacted by the support from MFIs.

4. What reasons trigger clients for leaving Micro finance institutions? (5: Strongly Agree \& 1: Strongly Disagree)

\begin{tabular}{|r|l|l|l|l|l|l|}
\hline S.N. & Reasons & $\mathbf{5}$ & $\mathbf{4}$ & $\mathbf{3}$ & $\mathbf{2}$ & $\mathbf{1}$ \\
\hline a) & Lack of grace period & 0 & 1 & 2 & 17 & 33 \\
\hline b) & Interest rate too high & 0 & 0 & 1 & 11 & 40 \\
\hline c) & Inability to repay loan for family reasons & 0 & 0 & 0 & 11 & 40 \\
\hline d) & Didn't like program savings requirement & 0 & 0 & 2 & 27 & 15 \\
\hline e) & Didn't need loan anymore & 0 & 1 & 5 & 32 & 13 \\
\hline f) & Didn't like periodicity in repayment & 0 & 0 & 0 & 32 & 19 \\
\hline g) & Others (e.g., rude officials, sickness) & 0 & 2 & 6 & 37 & 6 \\
\hline
\end{tabular}

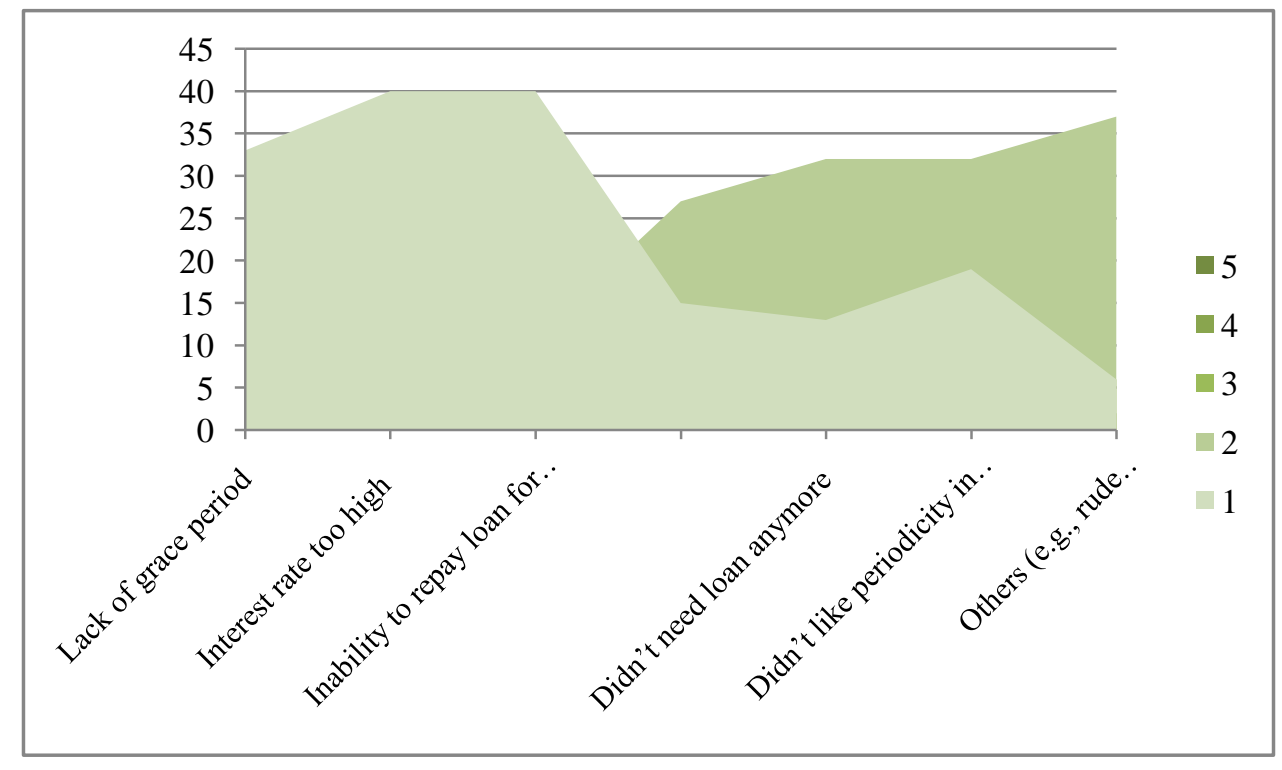


Inference: Most of the respondents disagree that high interest rate and inability to repay loan family reasons behind leaving MFIs. This is very surprising that high interest is not the prime concern for the borrowers also.

5. Have you/your clients been impacted in following ways after MFI support/association? (5: Strongly Agree \& 1: Strongly disagree)

\begin{tabular}{|c|l|l|l|l|l|l|}
\hline S.N. & $\mathbf{5}$ & $\mathbf{4}$ & $\mathbf{3}$ & $\mathbf{2}$ & $\mathbf{1}$ \\
\hline a) & Learned savings skills & 34 & 8 & 6 & 3 & 0 \\
\hline b) & Able to meet basic family needs & 36 & 5 & 6 & 4 & 0 \\
\hline c) & Business has grown & 32 & 18 & 0 & 1 & 0 \\
\hline d) & Business-related training was helpful & 40 & 9 & 2 & 0 & 0 \\
\hline e) & Able to pay school expenses & 34 & 13 & 3 & 1 & 0 \\
\hline f) & Have more household assets now & 27 & 12 & 12 & 0 & 0 \\
\hline g) & Have gained confidence and self-esteem & 32 & 13 & 6 & 0 & 0 \\
\hline h) & $\begin{array}{l}\text { Now able to use money more optimally in household and } \\
\text { business }\end{array}$ & 37 & 14 & 0 & 0 & 0 \\
\hline i) & Gained leadership experience & 40 & 11 & 0 & 0 & 0 \\
\hline j) & Other skills training was helpful & 38 & 13 & 0 & 0 & 0 \\
\hline k) & Have a place to put my savings & 32 & 9 & 10 & 0 & 0 \\
\hline
\end{tabular}

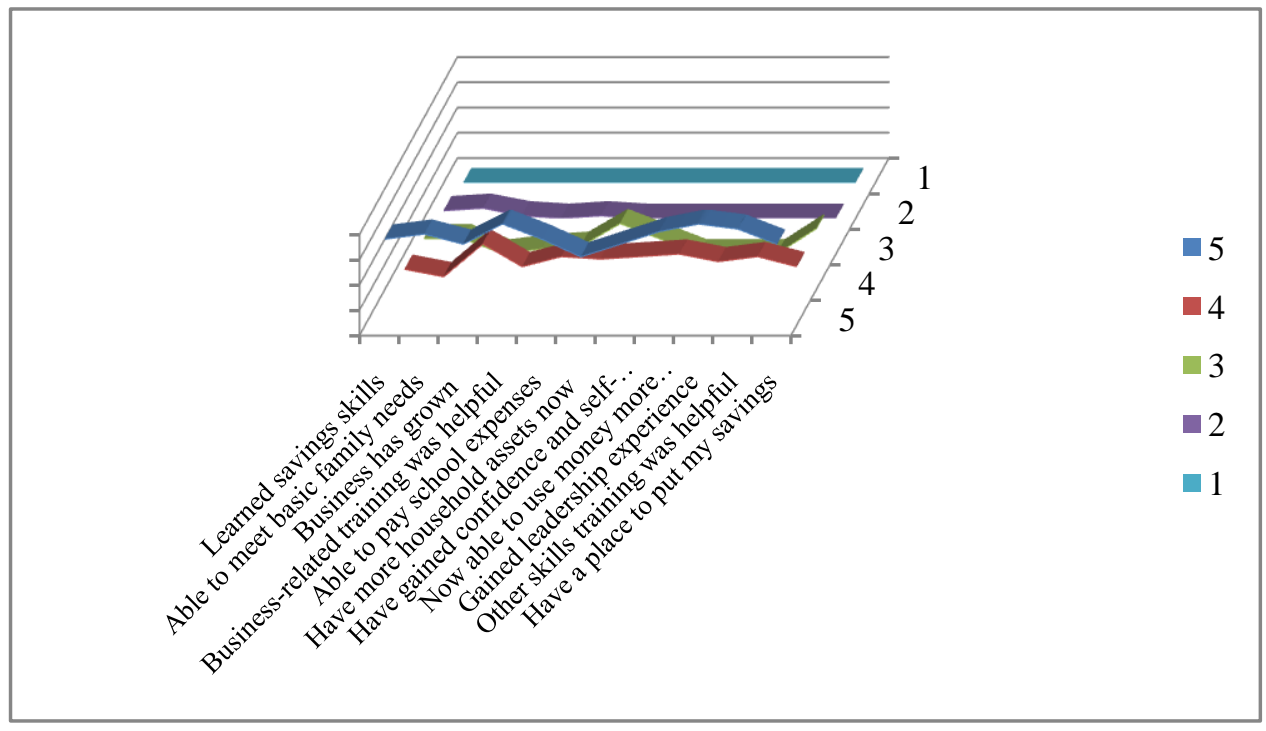

Inference: Most of the respondents agree that they were impacted positively after MFI's support in the form of business related training, leadership experience and optimal use of money.

6. Do you think the following cost heads in providing/availing Microfinance services work in your favor?

\begin{tabular}{|c|l|c|c|c|c|}
\hline S.N. & \multicolumn{1}{|c|}{ Cost Head } & $\begin{array}{c}\text { Above } \\
\text { Industry }\end{array}$ & $\begin{array}{c}\text { At par with } \\
\text { Industry }\end{array}$ & $\begin{array}{c}\text { Below Industry } \\
\text { Standards }\end{array}$ & $\begin{array}{c}\text { Can't } \\
\text { Say }\end{array}$ \\
\hline a) & Cost Per Active Client & 18 & 32 & 0 & 1 \\
\hline b) & Borrower per loan officer & 9 & 40 & 2 & 0 \\
\hline c) & $\begin{array}{l}\text { Average Outstanding loan } \\
\text { size }\end{array}$ & 13 & 34 & 3 & 1 \\
\hline d) & Average loan disbursed & 12 & 27 & 12 & 0 \\
\hline
\end{tabular}




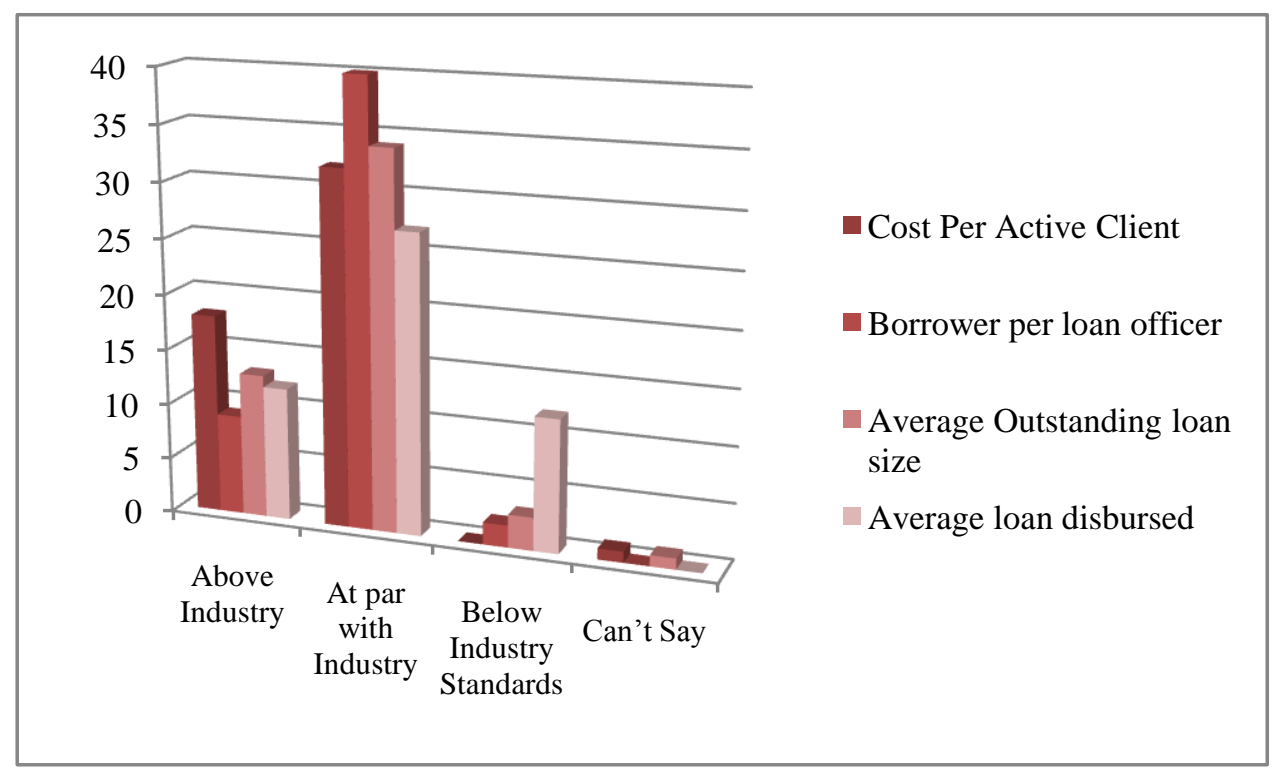

Inference: Most of the respondents agreed that the various cost heads such as cost per active client, borrowing per loan officer, average outstanding loan size and average loan disbursed was at par with the industry.

7. How would you rate your services/your service provider on the following points?

(5: very good \& 1: very bad)

\begin{tabular}{|c|l|c|c|c|c|c|}
\hline & Parameter & $\mathbf{5}$ & $\mathbf{4}$ & $\mathbf{3}$ & $\mathbf{2}$ & $\mathbf{1}$ \\
\hline a) & On time Service delivery & 27 & 10 & 10 & 4 & 0 \\
\hline b) & Exact and precise service delivery & 30 & 14 & 7 & 0 & 0 \\
\hline c) & Your service provider is dependable & 32 & 18 & 0 & 1 & 0 \\
\hline d) & They have delivered service as promised & 29 & 18 & 2 & 2 & 0 \\
\hline e) & You feel safe in all transactions with the service provider & 37 & 10 & 4 & 0 & 0 \\
\hline f) & Prompt response to customer request & 27 & 15 & 9 & 0 & 0 \\
\hline g) & Sincere interest in problem-solving & 32 & 13 & 6 & 0 & 0 \\
\hline h) & Responsiveness -Provision of adequate information & 32 & 9 & 10 & 1 & 0 \\
\hline i) & Advanced information about services & 40 & 11 & 0 & 0 & 0 \\
\hline j) & Reputation of service & 37 & 10 & 4 & 0 & 0 \\
\hline k) & Politeness of personnel's behavior & 32 & 12 & 7 & 0 & 0 \\
\hline l) & Cultivation of friendly relationship & 32 & 9 & 8 & 2 & 0 \\
\hline m) & Learning the customers' special needs & 32 & 10 & 6 & 3 & 0 \\
\hline n) & Allocating required time to deliver service & 23 & 19 & 7 & 2 & 0 \\
\hline o) & Modern and technologically relevant system & 42 & 9 & 0 & 0 & 0 \\
\hline
\end{tabular}




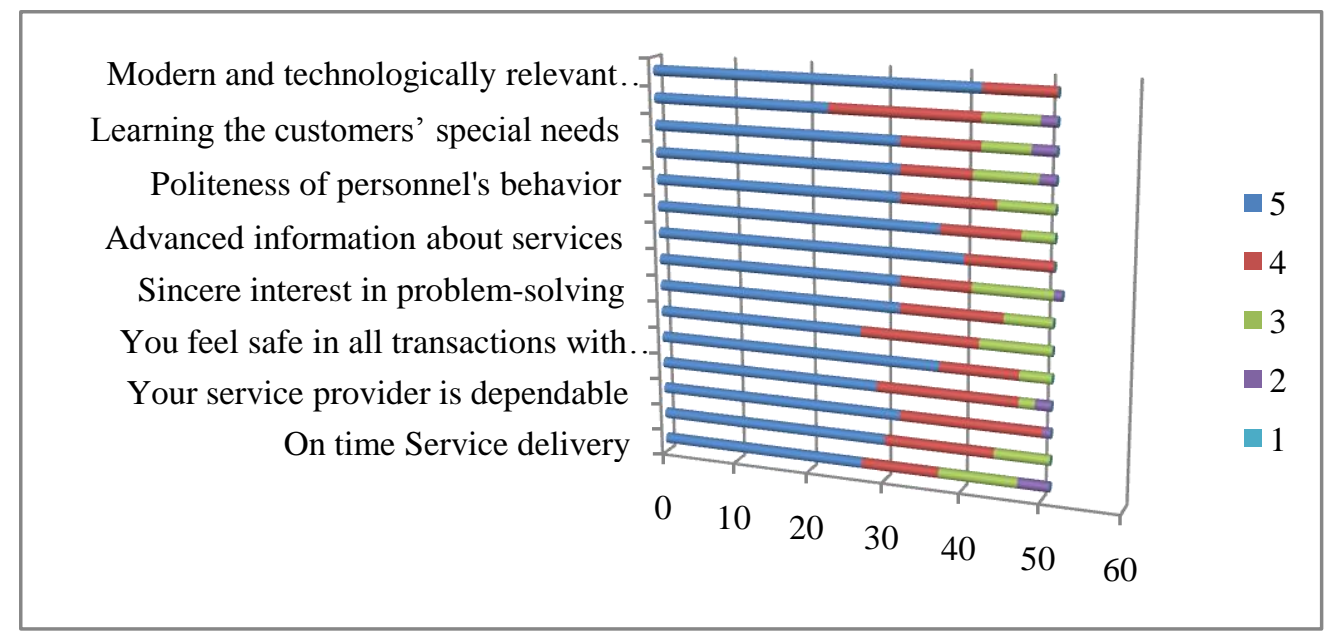

Inferences: In rating their service provider on the basis of various parameters given above, majority of the borrowers rated them as very good.

\section{FINDINGS AND CONCLUSIONS Lender/MFI's Perspective}

1. MFI's lend to individuals who are members of a credit group, provide loans to those whose businesses generate weekly cash flow, require group guarantee of loans, lend at commercial interest rates and require members to save.

2. Most of the banks are still not active in providing microfinance to the root level.

3. Most of the MFI's agree towards the importance of Client savings, low interest rates, group peer pressure, access to future loans, regular monitoring by program members and careful application screening as important factors for loan repayment.

4. Most of the respondents agree that their clients were impacted through reduction in costs while buying in bulk and increased the household income.

5. The respondents strongly disagree the reasons for leaving micro financing institutions such as interest rate too high, inability to pay loan for family reasons while they agree that reasons for leaving MFIs are did not need loan anymore and did not like periodicity in repayment. Thus higher interest rates are not at all reasons for leaving Micro Finance institutions.

6. The respondents agree that the various cost heads like cost per active client, Borrower per loan officer, average outstanding loan size and average loan disbursed are at par with the industry.

\section{Borrowers Perspective}

1. Most of the respondents were male, middle aged from semi urban areas and they have participated through Self Help group. This shows that MFI's still has not penetrated in the rural areas.

2. Most of the respondents agreed to their access to future loans as the important factor for micro loan repayment while moderate response was towards less interest rate and group peer pressure.

3. Most of the respondents agree that borrowing from MFI's help them to reduce costs by buying in bulk and increase the amount of money they spent on inputs. Thus they are positively being impacted by the support from MFIs.

4. Most of the respondents disagree that high interest rate and inability to repay loan family reasons behind leaving MFIs. This is very surprising that high interest is not the prime concern for the borrowers also.

5. Most of the respondents agree that they were impacted positively after MFI's support in the form of business related training, leadership experience and optimal use of money. 
6. Most of the respondents rated their service providers to be very good in terms of various services like technology advanced information, exact and on time service delivery, feeling of safety in transactions and friendly environment.

\section{LIMITATIONS OF THE STUDY}

1. The sample size within each of sub- category analyzed in the study was not adequate to corroborate the findings.

2. Time is the major constraint of the research as the research had to do it in a time frame researchers were unable to cover few potential respondents.

3. Some sections of the questionnaires were not answered by respondents making it difficult to obtain and analyze data pertaining to those parts. This cause a level of non-response which may impact the validity and reliability of the results though not to material extent.

4. The environment under which the study was proposed change by the time data collection from the respondents started making difficult to get the desired result.

\section{References}

1. Acharya, U., Petheram, R. J. and Reid, R., 2004. 'Concepts and perceptions of biodiversity in community forestry, Nepal', Small-scale Forest Economics, Management and Policy, vol. 3, no. 3 (special issue), pp. 401-410.

2. ADBN, 2003. Progress report of Small Farmers Co-operative Limited as of Aswin month 2059/60, Agricultural Development Bank (ADBN), Microfinance Division (MFD), Head office, Kathmandu.

3. Bajracharya, P. and Bajracharya, S., 1999. 'Strategies for poverty alleviation: An integrated approach', Agricultural Credit,vol. 31, no. Bi-annual, pp. 15-21.

4. Baumann, T., 2004. 'Pro-poor Microcredit in South Africa: Cost-Efficiency and Productivity of South African Pro-poor Microfinance Institutions', Development Southern Africa, vol. 21, no. 5, pp. 785-98.

5. Bennett, L., Goldberg, M. and Hunte, P., 1996. 'Ownership And Sustainability: Lessons On GroupBased Financial Services From South Asia', Journal of International Development Special issue: Sustainable Banking with the Poor, vol. 8, no. 2, pp. 271-288.

6. Where to go for more information. Books/Articles: CGAP Disclosure Guidelines for Financial Reporting by Microfinance Institutions, provisional version (Wash., D.C: CGAP, January 2001); Committee of Donor Agencies for Small and Medium Enterprise/Donors' Working Group on Financial Sector Development, Micro and Small Enterprise Finance: Guiding Principles for Selecting and Supporting Intermediaries (Wash, D.C: World Bank, 1995); "Financial Intermediary Lending," World Bank Occasional Paper No. 8.30 (July 1998); Malcolm Harper, Profit for the Poor: Cases in Microfinance(London: Intermediate Technology Publications, 1998); Micro Banking Bulletin, No. 7 (November 2001); Richard Rosenberg, "Microcredit Interest Rates" (CGAP Occasional Paper No. 1, August 1996); Marguerite Robinson, The Microfinance Revolution: Sustainable Finance for the Poor, Vol. I (Wash., DC: World Bank, 2001).

7. Websites: www.microbanking-mbb.org, www.cgap.org/html/p_occasional_papers01.html.

8. Aleke, P. (1999).”Marketing in a networked economy", Journal of marketing (special issue).

9. AMFI (2010), 'Annual Report', CGAP Microfinance publication.

10. Burns and Grove (1993), Nursing research; Research; Methodology, 2nd edition; Sanders (Philadelphia).

11. CGAP (2003), 'Annual Report', CGAP Microfinance publication.

12. Cohen, Monique, "Making Microfinance More client-led”, Journal of international development (2001).

13. Cooper, D. R. and Schindler, P. S. (2006), Business Research Methods; 9th Edition, Tata McGraw Hill.

14. Tor Jansson, IADB, Micro-finance from village to Wall Street.

15. Bansal Hema (2003), "SHG - Bank Linkage Program in India: An Overview", Journal of Microfinance, Vol. 5 No's 1. 